\title{
Nathaniel Hawthorne And The Social Morality
}

\author{
Mohsen Mahmoud Rowshanzamir \\ Islamic Azad university, Mashhad Branch, English Department \\ E-mail: roshanzamir_mohsen@yahoo.com
}

Received: 04-06-2014

doi:10.7575/aiac.ijalel.v.3n.6p.243
Accepted: 03-08-2014

Published: 01-11-2014

\begin{abstract}
Nathaniel Hawthorne (1800-1864) who grew in the puritan environment of Salem, Massachusetts nourished worries regarding man and his relationship with the society on one hand and with his God on the other. On the whole he had some moral responsibility to fulfill in his writing carrier; the moral responsibility that he grew and tried to fulfill in his works of literature. This article tried to have a closer look at some of his major short stories to find his moral concerns regarding the social life. The analysis of the tales in this article suggested the supremacy and priority of social moral matters over individualistic moral concerns for Nathaniel Hawthorne as a social moralist.
\end{abstract}

Keywords: morality, individualistic concerns, social concerns, sin, moral decision, women

\section{Introduction}

Nathaniel Hawthorne presented many moral points which were learned through the struggles and challenges of the characters who faced many moral dilemmas where they had to choose between right and wrong. Hawthorne also emphasized on the theme of alienation. These concepts can be found in the stories "Young Goodman Brown", "The Minister's Black Veil," and "The Birth Mark" and some others. These short stories are all about decisions one must face and the consequences of that decision. A decision which changes the normal course of life. In "Young Goodman Brown," the main character found himself in a dilemma about the strength of his faith in God and the trust he lost for his wife and community. In "The Minister's Black Veil," a minister faced the struggle between his sins and the fear of their being revealed to his people. Finally, in "The Birth Mark," the main character became obsessed with a slight physical flaw on wife's face; an obsession that ultimately led to the destruction the thing he cherished most dearly.

The analysis of the tales in this article suggests the supremacy and priority of social moral matters over individualistic moral concerns for Nathaniel Hawthorne as a social moralist. He has tried to express his ideas and concepts through the use of allegories and symbols biblical or social to present his social moral concerns and the effect of individualistic immoral behaviors and what human being may inflict upon him through the moral choices he makes in everyday normal situations. Hawthorne's concerns are beyond personal ones. For him a healthy community is the result of healthy individuals; while in many of the cases individuals cannot reach prosperity in a wretched society.

This article tries to examine Hawthorne's major short stories to find his moral concerns and to enlighten the longstanding argument whether his moral concerns were of individualistic or social type. He made his characters play in normal human situations, at many of which they had to choose from among two or more moral choices, and they were free to have their choices. The readers then could see what they faced and got moral lessons. In his short stories, like his novels, Hawthorne, presented many moral themes, including sin, atonement, moral dilemma, and social rights of women and children. Hawthorne also emphasized on the theme of alienation.

\section{$1.1 \mathrm{Sin}$}

Hawthorne contributed to the establishment of the American short story as a significant art. In his tales, he presented human loneliness, frustration, hypocrisy, eccentricity, and frailty as the features facing human life. He also depicted a theme of sin as running through all his fiction; a theme which had occupied the seventeenth century Puritans.

Indeed, there is a certain complexity in the concept of sin as we find it in Hawthorne's fiction. The reader is confronted with several categories of sin, some more obvious than others. In some of Hawthorne's short stories, the characters' unconscious awareness of the original sin is transferred to a visible, physical burden. (Georgieva, 2009: 54).

Herman Melville (1996) believed: "that his great power of blackness in him derives its force from its appeals to that Calvinistic sense of Innate Depravity and Original sin.” (Parker, 1996: 19).

Georgieva in her article, "The burden of secret sin; Nathaniel Hawthorne's fiction", has outlined some of the important sins depicted in his works. She has referred to them as those committed physically on the body, sin in the form of a curse on the generations, or that hiding behind a veil (Georgieva, 2009). Gorgieva believed that Hawthorne in both his short stories and long romances referred to the man's expulsion from Eden as the result of eating from the tree of knowledge of Good and Evil: 
Many of the examples we mentioned are obviously related to the concept of knowledge. Much in line with the Biblical canon, Hawthorne's earliest interpretation of the original sin is connected to the sin of forbidden knowledge acquisition. The original sin of the first human beings was knowledge-Adam and Eve conquered their independence by taking the decision to consume the fruit of the Tree of Knowledge of Good and Evil. The first sin they became guilty of was the acquisition of knowledge. In spite of the understanding humanity now possessed, the fratricide committed by Cain demonstrated a conscious predisposition to perpetrating evil. (Georgieva, 2009: 56).

Like the previous critic but from a different angle, Denis Donoghue (2003), in his article "Hawthorne and Sin," explained the notion of original sin proposed by Hawthorne. He remarked that in Hawthorne, the notion of sin seems: "all general and vague" at first, while "none of the characters has a convinced sense of sin" in total accordance with the Biblical canon:

Donoghue explains that when Hawthome "referred to sin, he seemed to assume a force of evil so pervasive that it did not need to be embodied in anyone or in any particular action". There is a lot of truth in this remark, and it can be applied to the quasi-totality of Hawthorne's fiction (Donoghue, 2003: 52).

Also, in some of Hawthorne's tales, sin is a fact which was transmitted to younger generations by sinful parents and/or family members:

According to some Puritan doctrines, the guilt of the first humans was handed down from one generation to another. Hence, every child was to carry the burden of the original sin, the weight of which was more often than not increased by the addition of the sins of his own parents. "Indeed, the beginning of The Scarlet Letter informs the reader that the past is not dead." (Georgieva, 2009: 56).

In some of them, it was the society that commits sinful acts and these become unpardonable ones. The child in "The Gentle Boy" (1832) died in atonement of Quaker mass killings and because of nameless crimes: "The weight of an indelible stain of blood and of a large share of the awful responsibility is too heavy for him to bear "(Pearson, 1999: 154).

The gentle boy with his Christ-like role, was unconsciously aware of human evils, of religious "extravagancies, and [...] persecution" (Pearson, 1999:154). He was the one who has received the legacy of the original and the unpardonable sin. In "Young Goodman Brown" (1835), the main character was not clear if what he has seen is true and appears as a disillusioned figure. What Hawthorne indirectly suggested is that the contact with the darker side of the town people and their sins was the reason for his death as a cynical character (Georgieva, 2009). For Nathaniel Hawthorne, as a descendant of a long line of Puritans, morality was bi-dimensional. On the one hand, morality was formed on the basis of the relation between man and his God, and on the other, the relation between man and his fellow creatures in the society. Hawthorne tried to depict the first aspect in many ways. One of the most important ones is the violation of divine orders by man, which according to the Original sin Principle, is transferred to later generations.

\subsection{Knowledge}

In Hawthorn's short stories, one of the sources of sin was related to the concept of knowledge, which was very much in line with the Biblical teachings. Hawthorne's opinion of the original sin was connected to the sin related to the attempt of taking hold of forbidden knowledge. (Georgieva, 2009).

According to some basic Puritan principles, the guilt of the first humans passed from generation to generation. Therefore, every child was born to carry the burden of the original sin, and to pass it to the next generation. Indeed, in Hawthorne's idea, "the past [is] not dead"(Pearson, 1999: 155). Possibly, it is because of that past that Hawthorne himself changed his ancestral name (Georgieva, 2009). Actually, his statement refers to the common Puritan belief in the past $\sin$ and to its collective nature of guilt. The stories Hawthorne tells explore the characters' willingness to discover the hidden secrets that lie undiscovered under the complex symbols and taboos of "the Puritan instinct" (Pearson, 1999). The deepest wish of many of these characters nurture was to find out the exact nature of sin. In fact, Hawthorne's texts showed a frequent use of the words "know," "aware," "penetrate," "reveal." In addition, many of the story plots were based on a succession of repeated sins. Jac Tharpe suggests that these repetitions are a continuous quest of identity, "the search for identity and individuality is original sin, while the unpardonable sin is tyranny over the identity of another"(Tharpe, 1967: 125).

Many of his characters knew about this hidden, obscure burden and their "concerns involve knowledge [and] the study of human origins and purpose" (Tharpe, 1967: 125). Goodman Brown became the witness of a violation of divine rules and this, in part, led him to damnation. Goodman Brown had a secret. He had discovered and knows the nature of man. He had come to know himself. This was the knowledge like the one which was banned from Adam by God. Hawthorne, In "Ethan Brand" (1850), suggested, "There was something in the man's face which he was afraid to look at." (Pearson, 1999: 11).

Ethan Brand was actually obsessed with a strong desire to discover the nature of sin. The idea that Flames dance in Ethan Brand's eyes reminded us of the evil and of the fires of Hell. In "Ethan Brand" (1850), Hawthorne expresses that:

There was something in the man's face which he was afraid to look at". Ethan Brand is actually possessed with a fanatical desire to discover the nature of sin. He possesses knowledge and this is what terrifies those who look at his face and into his eyes. Flames dance in Ethan Brand's eyes, reminding the reader of the utmost evil and of the fires of Hell. Upon his return after a long absence, Ethan Brand watches a dog chase its tail, the symbol of the futility of his vain quest of self-knowledge. (Georgieva, 2009: 57). 
Returning after a long absence, Ethan Brand watched a dog chasing its tail, which was a symbol of the uselessness of his search for self-knowledge (Georgieva, 2009). Hawthorne suggested that Ethan Brand has gratified in the "sin of intellect that triumphed over the sense of brotherhood with man and reverence for God and sacrificed everything to its own mighty claims" (Hawthorne, 1983: 102).

Much in the same way, In the "The Minister's Black Veil," there is the same type of fear for most of the characters to look at Mr. Hooper's veil, perhaps because it hid his knowledge about a wide range of sins. He was a minister and the one who receives the sins of an entire congregation. The veil protects them from the knowledge the minister has. On the other hand, the minister's existence became increasingly dependent on that knowledge and this was why he rejected to take off his veil. It was the accumulation of knowledge, and not the pressure exercised on him to remove the veil, that made his burden heavier: "Reverend Hooper's acquaintances, friends and family members wanted "to penetrate the mystery of the black veil" and "to reveal the mystery of so many years" (Pearson, 1999: 124). Even Reverend Hooper's congregation "whispers that [he] hide[s] [his] face under the consciousness of secret sin" (Pearson, 1999: 124). This was one of the few cases that Hawthorne uses both words "secret" and "sin" to refer to the nature of Reverend Hooper's sin. This example showed what is probably one of the most delicate specifications of Hawthorne's conception of sin. The secret and the desire to know about it was the fact that drives the story forward and this secret is related to the sin. Hawthorne related the sin to a secret, a mystery.

Reverend Hooper, in his sermon, used reference to secret sin, and those sad mysteries, which we hide from our nearest and dearest, and would fain conceal from our own consciousness, even forgetting that the Omniscient can detect them.

When he preaches, the subject of Rev. Hooper's sermon had reference to secret sin, and those sad mysteries, which we hide from our nearest and dearest, and would fain conceal from our own consciousness, even forgetting that the Omniscient can detect them. ( Pearson, 2009: 59).

Both "The Minister's Black Veil" and "Young Goodman Brown" were good examples in that regard. In that case, they had to carry the burden of their guilt to death, although they did not seem to accept their sin. One important implication of the secret sin was their inability to have a true communication with their community and they could not enjoy a collective moral attempt to reach salvation:

Secret sin gradually becomes an idée fixe with a large scope of implications. The sinful characters struggle with the inability to communicate effectively and their incapacity to contribute to a collective moral effort bars the way to compassion. They become withdrawn and distant and the fact that they preserve their secret sin damages their body and soul. (Georgieva, 2009: 60).

In this way, they became recluse, withdrawn and distant and keeping their secret sin destroys their body and soul. Accordingly, many of Hawthorne's secret sinners appeared as socially recluse individuals or as lonely wanderers and aimless confused persons. Hawthorne introduced many secondary background characters who, in the course of the story, could be regarded as counterparts of the reader. In fact, Hawthorne was cautiously "remolding the old Puritan sense of the burden of sin with an artistic delicacy" (Gorman, 1927). After surface reading of the stories, one may come to the conclusion that knowledge should no longer be considered a sin. To Hawthorne knowing was not a sin but keeping the knowledge for oneself is a sin. Reverend Hooper kept his awareness of $\sin$ to himself; which was a $\sin$ committed toward those who loved him and the members of his community.

Beyond the first reading and under the surface of the text lies the idea that knowledge should no longer be considered a sin. To Hawthorne knowing is not a sin but keeping burdensome knowledge for oneself is sin. "The fact that Rev. Hooper keeps his awareness of sin to himself is sinful toward those who love him and toward the members of his congregation." (Georgieva, 2009: 60).

In "Earth's Holocaust" (1844), Hawthorne told us "this wide world had become so overburdened with an accumulation of worn-out tampering, that the inhabitants determined to rid themselves of it by a general bonfire." (Hawthorne, 1983: 61). This story summarized Hawthorne's conception of secret sin:

Contrary to what it appears, the burden of secret sin is not something personal. Actually, secret sin is a shared responsibility. It is a collective burden. The yoke of secret $\sin$ is heavier than that of the original sin because our immediate ancestors are to be held accountable for it. (Georgieva, 2009: 62).

Although it seemed that a sin, especially a secret one, was something personal, it was a burden on the whole community; in other words it was a collective burden. "However, Hawthorne seemed to say that human being was responsible for what he did, and hiding it only made it worse." (Bama, 1998).

What Hawthorne tried to show was the darkness of a society in which the members try to play hypocrite, while they know they are deep in sins. In this society, the people get used to play roles and tell lies regarding their puritan ways, while they try to show off goodness and chastity, a chastity that had no root in their hearts. It is clear that purity would never be established and social morality without safe foundations would never lead to prosperity.

\subsection{Moral Decisions}

One of the themes which were of great significance to Hawthorne was morality as he saw it through challenging moments of decision making (Miller, 1991). Hawthorne's characters found themselves making decisions at vital decision making points, as they had to choose between good or devil, in other words, morality and immorality. (Mellow, 1980). Such themes can be easily seen in "Young Goodman Brown", "The Birth Mark", and "Minister's Black Veil", to mention only a few. In all these stories, the important decisions taken by the characters change their 
lives (Kaul, 1966). "Young Goodman Brown" is the story which shows the importance of moral decision based on faith the character nourishes in his heart. The main character has lost trust in his wife, which is a symbol of his faith, and his community. Hawthorne showed this mistrust and anxiety in the best form possible.

"Young Goodman Brown" was the story of a good natured- man, Hence the name of the story. He left his wife, called Faith, who is a symbol of his religious faith, innocence and purity. He starts a fateful journey. He faced devil temptations in the forest and changes as the devils in the forest made him loose his faith in the community he was living in. Again, Young Goodman Brown had to decide between the evil temptations surrounding him and the religious purity and a faithful life. From the beginning of his journey, he knew the facts and he is afraid the outcomes.

In this story, names are symbolically loaded. Young Goodman brown is a normal human being with good and evil aspects. His wife, "Faith", was also a symbol of religious faith, purity, and perfection:

Young Goodman Brown came forth at sunset into the street at Salem village; but put his head back, after crossing the threshold, to exchange a parting kiss with his young wife. Faith, as the wife was aptly named, thrust her own pretty head into the street, letting the wind play with the pink ribbons of her cap while she called to Goodman Brown. "Dearest heart," whispered she, softly and rather sadly, when her lips were close to his ear, "prithee put off your journey until sunrise and sleep in your own bed to-night." (Hawthorne, 1883: 15).

This also referred to the innocence and the religious faith and the community he left behind. Hawthorne again tried to show the link between individualistic and social moral matters. He accepted the evil spirits by entering into the dark forest by leaving behind his personal faith and the social religious norms of his society (Harris, 1988). The first point at which he had to make a decision was at entering the forest. He was conscientiously aware of the action he was launching, because of this, he was afraid of walking in the forest. At the beginning he ran into an old man holding a serpent representing Devil of which the character was afraid. Hawthorne tried to show the role moral conscience plays in wakening human being. In this regard, there were some clues in their first conversation they had:

He arose at Goodman Brown's approach and walked onward side by side with him. You are late, Goodman Brown, said he. The clock of the Old South was striking as I came through Boston, and that is full fifteen minutes agone. Faith kept me back a while, replied the young man, with a tremor in his voice, caused by the sudden appearance of his companion, though not wholly unexpected. (Hawthorne, 1983: 16).

At first, he could resist the Devil strongly, as in his reply to the Devil's question why he was late. He lost faith and followed the devil into the forest of faithlessness. At last, he saw all the people, among them his own Faith, busy doing devilish rituals; which was a symbol of his loss of faith, he caught sight of the pink ribbon in the sky. The pink ribbon was the symbol of deserted faith. The next day, he was not sure if what he had seen was a dream or reality. With no religious faith, one could not find a way to the realities of the society. With a faith destroyed, ha could not trust anyone even his wife Faith. He took asylum in alienation and died a miserable and lonely man:

Often, waking suddenly at midnight he shrank from the bosom of Faith; and at morning or eventide, when the family knelt down at prayer, he scowled and muttered to himself, and gazed sternly at his wife, and turned away. And when he had lived long, and was borne to his grave a hoary corpse, followed by Faith, an aged woman, and children and grandchildren, a goodly procession, besides neighbors not a few, they carved no hopeful verse upon his tombstone, for his dying hour was gloom. (Hawthorne, 1983: 24).

Hawthorne emphasized on the idea that individualistic morality led to social moral structure, and lack of good faith will lead to alienation and destroyed social communication among the individuals. A community without moral foundations consisted of the immoral individuals.

Another dilemma between morality and religious faith was presented in the "The Minister's Black Veil". In "The minister's Black Veil", there was again the story of taking an important decision and the fear of its out comings. The character was worried about his sins and their being revealed to the community. He had to decide about how to control his worries and keep them hidden. He was thinking of whether to reveal or keep it and the out comings of both ways. "The Birth Mark" was the story in which Hawthorne depicts a character who gets obsessed with a small mark on his wife's face. To remove it or to let it remain is a decision he had to make; as the result of that decision, he destroyed the love he had kept in his heart (Elliott, 1994). The main character, Hooper a religious leader, was wearing a black veil to disguise his sins. He felt guilty about them but his pride and fear of their disclosure made him wear black veil to hide the realities. (Kaul, 1966). The veil did not hide his sins, but represented him as sinister and evil:

It grieved him, to the very depth of his kind heart, to observe how the children fled from his approach, breaking up their merriest sports, while his melancholy figure was yet afar off. Their instinctive dread caused him to feel more strongly than aught else, that a preternatural horror was interwoven with the threads of the black crape.... (Hawthorne, 1983: 45).

By not unveiling, Hooper was committing another sin; that of pride. In reality, the veil is a barrier, which did not let him see his guilt of pride. He was a minister who preached and absolves others, while he was deep in hypocrisy. He wore the veil to hide his sins from the public disclosure but the people were sure he was hiding his evil personality. His personal sin led to his social alienation:

Still veiled, they laid him in his coffin, and a veiled corpse they bore him to the grave. "The grass of many years has sprung up and withered on that grave, the burial stone is moss-grown, and good Mr. Hooper's face is dust; but awful is still the thought that it moldered beneath the Black Veil!" (Hawthorne, 1983: 48). 
Much in the same way, Hawthorne presented the themes of morality and alienation in "The birthmark". The main character, a scientist, had the idea that the birthmark on his wife's face represents her evil character, and to save her soul, it should be removed. In the course of the operation, she lost her life. Here, the birthmark acted like a veil, which hid her true beauty and purity and represent her as evil:

No, indeed, said she, smiling; but perceiving the seriousness of his manner, she blushed deeply. To tell you the truth it has been so often called a charm that I was simple enough to imagine it might be so. Ah, upon another face perhaps it might, replied her husband; but never on yours. no, dearest Georgiana, you came so nearly perfect from the hand of nature, that this slightest possible defect--which we hesitate whether to term a defect or a beauty--shocks me, as being the visible mark of earthly imperfection (Hawthorne, 1983: 50).

"He was very much obsessed with the mark at the expense of ignoring her beauty and purity. For him, the mark was a symbol of her defect and his own fear of alienation." (Elliott, 1983). He made a potion that kills her:

And what is this? asked Georgiana, pointing to small crystal globe containing a gold-colored liquid. It is so beautiful to the eye that I could imagine it the elixir of life. In one sense it is, replied Aylmer; or, rather, the elixir of immortality. It is the most precious poison that ever was concocted in this world. By its aid I could apportion the lifetime of any mortal at whom you might point your finger. (Hawthorne 1983: 56).

Aylmer ignored the fact that she had other perfect spiritual characteristics other than physical beauty; the characteristics he destroyed because of his egoistic orientation to his wife and her rights as a human being (Harris, 1988).

"The Birthmark" stood to represent a multitude of things. It represented the desire for the simplicity of scientific explanations; it was a symbol of the downfall of society through science and technology, and a symbol of the imminent death that was to come for Georgiana, the wife, thus representing the need for spiritual insight and intuitive understanding (Stewart, 1984).

Hawthorne as a storyteller also created situations of moral complexity in which conventional standards of right and wrong provide little guidance to help eradicate the confusion. A good example in this regard was his short story, "Roger Malvin's Burial" which was considerable from the view point of moral perplexity and doubt (Colacurcio, 1993). This is a short story in which human being is dealing with the question of choosing right from wrong in a situation in which both apparently weigh the same and he has no contribution from the usual goodness criteria. Hawthorne has examined situations in which a person is facing ethical complexities; Colacurcio (1993) brilliantly referred to positions rooted in the recognition that sometimes we cannot be sure of our own motives. There are also themes of atonement and allegories of Original Sin:

These closing words of the story, like the Biblical allusions throughout, make it clear that a reading of the tale in terms of both primitive religious myth and the historical and theological aspects of creedal Christianity are as clearly justified as the psychological reading is. (Colacurcio, 1993: 74).

As Reuben Bourne and Roger Malvin tried to make their way out of the forest, they faced a moral dilemma. Malvin would not survive the long journey, and if Reuben waited with him, he would also die. Hawthorne illustrated Reuben's decision making as complicated as possible. He showed how one person's doubt in moral situations affected his life as long as others. Reuben did leave, but Hawthorne cast many doubts on his motives.

Reuben was never sure of the reasonability of what he did; in fact, he was ruined with guilt and suspicion that he left his companion for selfish reasons (Carlson, 1977). In effect, there was no way for Reuben to get rid of the burden of the dilemma he has faced. In "Roger Malvin's Burial", in the woods with his severely wounded future father-in-law, Reuben faced a very difficult moral decision to take. He must decide whether to stay and die with Roger or try to escape from death and save himself by leaving. His father-in-law urged him to go, but asked Roger to return and bury his corpse. After leaving him, Reuben feared losing his future wife if he told the truth, so he said: "My hands were weak, but I did what I could .. . There stands a noble tomb-stone above his head, and I would to Heaven I slept as soundly as he!" (Hawthorne, 1983: 117). He embarked on a chain of moral failures. Then Reuben began to feel guilty, not for leaving Roger, but because "concealment had imparted to a justifiable act, much of the secret effect of guilt." (Colacurcio, 1993). Although Reuben's dishonesty preserves his relationship to Dorcas and his stature in the community, guilt destroys his life: "Miserable with himself, he behaves miserably to others. He loves only his son, Cyrus, "as if whatever was good and happy in his own nature had been transferred to his child, carrying his affections with it." (Bunge, 1993: 14).

In all these short stories, Hawthorne created a character who had to decide at a critical point. In "Young Goodman Brown", "The Minister's Black Veil", "The Birth mark", and "Roger Malvin's Burial" the main characters were religiously faithful. They tried to remain faithful and reach piety; however, as the result of their wrong choice, they went stray from the personal moral way which led them to social immorality. Young Goodman Brown, suffering from a weak faith, started a journey which he, himself, was not sure about its reality. He lost his faith and easily led to a social alienated life (Buell, 2006). Again, hawthorn, tried to focus on the importance of personal morality. He was showing us that many social moral problems that individuals face came from their lack of personal basis in individualistic moral foundations. As a result, individualistic moral ideas led to a decent communal heath.

In one of his less known short stories, "The Great Stone Face", Hawthorne dealt with such themes as moral imagination, insight, and virtue. He emphasized on the importance of having high personal moral ideals and virtue 
basis, at first hand, over the social moral models. This story draws a moral "concerning the values inherent in domesticity and the futility of searching abroad for something to be found more surely at home" (Person, 2007: 111).

In this story the people in a valley, were waiting for a great person to appear. This person, who was modeled on the Great Stone Face on the mountain side, would be a moral leader and would lead them to prosperity and happiness. The main character in the story was powerfully influenced by what he sees in that great stone face on the mountain side (Pojman, 2000). It seemed that Hawthorne again tried to enlighten the important role individualistic moral basis plays in person. He tried to show that unless individuals do not hold a sound moral basis, the community would not reach a safe moral system and a moral society consisted of individuals who are powerful in individualistic moral believes.

\subsection{Issue of Women}

Hawthorne's lifetime (1804-64) spanned a period of great and rapid change when, in little over half a century, America transformed itself politically, economically, and in its social arrangements. One of these great changes was the change in the role women started to play. Hawthorne had a specific view regarding the issue of women:

Nathaniel Hawthorne was one of the first writers to feature women as prominent figures in his literary works. He got the idea to use women characters from Sir Walter Scott, who changed the role of women characters forever when he wrote the novel, The Heart of Midlothian. In this work, no stereotypical roles were assigned to his female characters such as Magdalene, Eve, and Madonna, the wife of Bath, drudge, or vampire. In Hawthorne s works, "The Scarlet Letter", "Rappaccinni's Daughter", and "The Birth-mark", each female character is portrayed as unique and unconventional. Hawthorne expanded the characters of women through his use of five recurring themes: the nature of women, the power of passion, the discovery of evil, the problem of guilt, alienation, pride, and initiation. According to some, Hawthorne is able to capture the beauty and intensity of the female character because of his upbringing" (Ellis, 1993:13).

Post-Revolution family structures and values gradually but significantly altered, placing new emphasis on a love relationship between husband and wife and on nurturing self-governance in children, and rather less on wider kin and community relations. There was an accompanying shift away from traditional categorizing of women in terms of subservience, weakness, and inferiority toward a notion of the tender female "heart"; women's social dependency was reconstructed as a female concern for others. So, while women might want the same increased opportunities as men and indeed some did paid work in the burgeoning capitalist economy until the late 1830s, new sex role distinctions were firmly in place by the end of the eighteenth century that would eventually pin most married white women and unmarried middle-class women to the home. In the late 1830s the middle-class home emerged, re-imagined as a private sanctuary from the world of money-making. In his short stories, he tried to show changes in women's lives and their improving role and social status. The picture he illustrated of them was a complex one; something between belonging to male dominated Puritan traditional society and a transcendental, feminist one (Fryer, 1976).

As a matter of social morality, the picture Hawthorne illustrated of women and children in many of his short stories was representative of his moral concerns over the women's right in a masculine Puritan community. "Despite many of his predecessors or even contemporaries, he never viewed woman as unimportant or as threatening, but rather as men's vital, emotional, intellectual, and spiritual partners." (Easton, 2004). In fact, in American literature, Hawthorne was the first or one of the first writers who was brave enough to have a woman play a key role in instead of being only a victim in his short stories. To him, women were not only a part of the society, but also as having social human rights. He had created a wide range of different female characters; good example could be found in tales like "The Birth-Mark," "Rappaccini's Daughter," "The Minister's Black Veil," "Young Goodman Brown," and "The Artist of the Beautiful" (Stewart, 1984). Many of his female characters had been depicted as serving figures for men and have isolated themselves from the community, because of the proud or aggressive personality of the male characters. These women had been presented as victims of men, destroyed by male power, aggressiveness, pride and masculinity: Faith in "Young Goodman Brown," Dorcas in"Roger Malvin's Burial," Catharine in "The Gentle Boy," and Mrs. Wakefield in "Wakefield, to name the most familiar (Stewart, 1984). What Hawthorne had in mind was a criticism of his contemporary gender relation in his society. The role of social relationships in forming female characters and that of emotion as well as reason in human experience was of prime importance to him. Hawthorne was sympathetic to female characters in his works to show his moral concern over the complexity and difficulty of women's situations at times of such great social change, whether in his own day or in the past.

Hawthorne talks about women to convey his opinion. Even in some cases he presents a dark picture of the women to have targeted both sexes equally. In "Rappaccini's Daughter" he depicts Beatrice as a carrier of deadly poison:

In the short story, Rappaccinni's Daughter, Hawthorne wrote about the concerns and consequences of men wanting to control women. He wanted to show how some men want to control everything that women do and every aspect of their being. The main character, Beatrice, is the first of Hawthorne s fully developed women dark, exotic, and ambiguous in her poisonous combination of sexual attractiveness and angelic purity. He shrewdly portrays Beatrice as an Eve still trapped and controlled by three individuals. In the Bible, God, Adam, and the serpent controlled Eve. (Ellis, 1993:356).

However, in Rappaccinni's Daughter, there are some men who find women threatening and might wish to remove them. Giovanni, her lover and potential future husband, is the person who thinks and desires her sexuality, yet he is anxious of her power to dominate and destroy him. "For Giovanni, sexual attachment to Beatrice means death in because being ruled by a woman, who would take his independence away, will be equal to destruction. Beatrice never tried to keep him in love him." (Ellis, 1993:356). 
In "Young Goodman Brown", Faith was a character who was lost to the Devil. In both "Rappaccini's Daughter" and "The Birthmark", Hawthorne also used men as transmitters of evil. The men involved in the stories had their own flaws which contribute to the flaws of the women in their lives. Through this equal negative role portrayed both by men and women, he tried to emphasize on the equal part both sexes have in good or evil they shared (Male, 1957).

Another short story "Lady Eleanore's Mantle" was a story in which one moral defect, pride, is portrayed. In this story, Hawthorne created a female character that was, somehow, similar to some other female characters. Lady Eleanore was independent-minded like Hester Prynne, yet has neither Hester's affection nor her compassion. Eleanore was beautiful like Young Goodman Brown's wife, Faith, but without spirit of kindness. Eleanore was full with attitude and conceit, which leads her to the final tragedy. Like Alice Pyncheon, Lady Eleanore becomes a mysterious presence, ghost-like in her haunting of the Province House at the end of the tale (Stewart, 1984).

Melissa Pennell (1991) has noted that: "from psychological perspective, critics explore the story's reflections of Hawthorne's personal anxieties about women in his life and about the nature of masculinity", while "feminist critics have examined its treatment of the images of woman, especially in light of gender roles in the nineteenth century" (Pennell, 1991: 86).

Richard Millington in his lecture "The Meanings of Hawthorne's Women" suggested that the story presented a critique of the malfunctioned masculinity of the nineteenth century that worked toward the destruction of female characters. Roy Male (1957) in his interpretation of "Rappaccini's Garden" in 'Hawthorne's Tragic Vision" was one of the famous readings of the tale. In regard with the moral of the story, he believed that if man was to reach full human potentiality, he must have accepted the woman and her dual promise she presented: tragic involvement with sin and the consequent possibility of redemption (Male, 1057).

Along with Hester Prynne, Miriam and Zenobia, Beatrice was a temptress; she played the role of an American femme fatale in nineteenth-century Romantic literature. Judith Fryer states in "The Faces of Eve" that Giovanni was unable to accept the sexuality and sinfulness of Beatrice; this is what happens for Young Goodman Brown. Through refusing to accept her dual potentiality, Giovanni did not realize the fact that it was also through her that redemption and full human potential could be achieved (Fryer, 1976).

Throughout his life, Hawthorne was fascinated by feminine purity, and treated them in such early tales as "Young Goodman Brown "and "The Minister's Black Veil", "Rapaccinni's daughter", My Kinsman, Major Molineux, "The Gentle boy", "The Wives of the dead", "The Birthmark", to mention only a few. His anxiety over the women's right in the changing nineteenth century America deepened as the years passed (Easton, 2004). According to Margaret Fuller (1845), the greatest feminist thinker of nineteenth century America and the writer of "Woman in the Nineteenth Century", as the result of Great social changes in nineteenth century in America, women were not separated from the public life, nor were men detached from the domestic, but that all lived a common world, of course differently (Fuller, 1999). "For sure, it could be concluded that Hawthorne had been affected with the wakening feminine movements. He supported it and moved along with it.' (Fuller, 1999).

Apart from the issue of women and their rights in the society, Hawthorne nourished another theme of social morality, which makes up one of his major themes: children.

In his short story "The Gentle Boy", Hawthorne presented his criticism of and condemns the intolerance of early Puritan settlers. In this short story he introduced one of his major moral themes: the orphan child whose parents has abandoned him or have been killed or have been displaced because of the force of the society. In fact, it seems that, he is focusing on the child's need for father and mother, home and caressing hands, for love and security, and support. The story of "The Gentle Boy" is set in: "Hawthorn's archetypal Puritan, bringing together the worst extremes of Puritanism: intolerance, iconoclasm, and persecution" (Newberry, 2003: 48).

The story is about a Quaker child whose father has been executed by the Puritans. In several parts of the story, the author draws the readers' attention to his misery and loneliness as a young boy in need of affection and support. An example was the scene of his weeping on his father's grave at night, while having no food to eat nor anywhere to go. The boy, who was weak and feeble because his only food had been a share of his father's ration in jail, at that young age was aware of the cruelty of the society, when a less fanatical Puritan tried to take him home for food and place to sleep, he expressed: “... though I be hungry, and shivering with cold, thou wilt not give me food nor lodging..... my father was of the people whom all men hate" (Hawthorne, 2003: 34).

This seems the highest and the harshest criticism, Hawthorne directly expressed against the cruel behavior against the children in society and their victimization. In this short story, readers faced many instances of cruelty against women and members of minority religious groups. The whipping if the Ibrahim's mother Catherine by the villagers and other Puritans is one example of those illustrations. The boy's mother "had been taken from the prison a short time before, carried to the uninhabited wilderness, and left to perish by hunger and wild beasts" (Hawthorne, 2003: 35).

In addition, the people of the town had a harsh misconduct with an elderly religious minority member is another example of cruelty. It seemed that Hawthorne through tempering sympathy for victimized women, children, and the elderly was trying to emphasize on those moral aspect of social life without which social morality is incomplete. Hawthorne led his readers. In fact, his recurrent character of the orphan victimized children first appeared in "The Gentle Boy". "By the time he completed his opus, more than thirty orphan children, all bearing heavy burdens, appeared in Hawthorne's works to feel compassion for these social victims." (Miller, 1991). 


\section{Conclusion}

Nathaniel Hawthorn who was born during Puritan times, created many stories that were reflections of his life experiences as a Puritan. He wrote many short stories that came to an end with a moral point which were learned through the struggles and challenges of the characters who faced many moral dilemmas where they had to choose between right and wrong. Hawthorne also emphasized on the theme of alienation. The major themes of sin, atonement, and moral dilemma have been presented in his short stories. Throughout his writing carrier he emphasized on the role of individualistic moral behavior and how he believed they might affect on the moral health of the society. He presented his individualistic and social moral concerns through his short stories in the form of his works of art and his writing style.

A study of Hawthorne's short stories reveal the priority of social moral concerns for him. The analysis of the Hawthorne's short stories mentioned in this article suggested the supremacy and priority of social moral matters over individualistic moral concerns for Nathaniel Hawthorne as a social moralist.

He has tried to express his ideas and concepts through the use of allegories and symbols biblical or social to present his social moral concerns and the effect of individualistic immoral behaviors and what human being may inflict upon him through the moral choices he makes in everyday normal situations. Nathaniel Hawthorne was a social writer who had social moral concerns. For him human being and his society have mutual impact on each other. Hawthorne's concerns are beyond personal ones. For him a healthy community is the result of healthy individuals; while in many of the cases individuals cannot reach prosperity in a wretched society.

\section{References}

Turner, A. (1980). Nathaniel Hawthorne: A Biography. New York: Oxford University Press.

Bama, M. R. (1998). Nathaniel Hawthorne and the Unpardonable Sin. World , 13, $22-27$

Delany, B. (1991). Nathaniel Hawthorne. Ed. Frank N. Magill, vol.2. NewYork: Salem.

Brenzo, R. (1986). Beatrice Rappaccini: A Victim of Male Love and Horror. Nathaniel Hawthorne. Ed. Harold Bloom. New York: Chelsea House Publishers.

Buell, L. (2006).The American Transcendentalists: Essential Writings. New York: Modern Library.

Bunge, N. (1993). Nathaniel Hawthorne: A Study of the Short Fiction . New York: Twayne Publishers

Colacurcio, M. J. (1993). Certain Circumstances: Hawthorne and the Interest of History in New Essays on Hawthorne's Major Tales. Cambridge: Cambridge University Press.

Donoghue, D. ( 2003). Hawthorne and Sin. Christianity and Literature. 52, 52-59

Easton, A. (2004). Hawthorne and the question of women in The Cambridge Companion to Nathaniel Hawthorne. Edited by Richard H. Millington. Cambridge: Cambridge University Press.

Edwards, J. (1966). Christian Doctrine of Original Sin Defended. In Basic Writings. Ed. Ola Elizabeth Winslow. New York: Penguin Books.

Elliott, E. (1994). New England Puritan Literature. The Cambridge History of American Literature. Cambridge: Cambridge University Press.

Ellis Barbara. “Some Observations about Hawthorne's Women”.// Willa, Vol. 2. 1993. P.13.

Fryer, J. (1976). The Faces of Eve: Women in the Nineteenth Century American Novel. New York: Oxford University Press.

Fuller, M. (1999). Woman in the Nineteenth Century. Papers on Literature and Art. London.Wiley\&Putnam. 1846. Woman in the Nineteenth Century. Mineola. New York: Dover publications.

Georgieva, M. ( 2009). The Burden of Secret Sin: Nathaniel Hawthorne's Fiction, cited in Critical insights of Nathaniel Hawthorne. Salem: Salem Press.

Gorman, H. (1927). Hawthorne: A Study in Solitude. New York: George H. Doran Company on Murray Hill.

Harris, K. M. (1993). Hypocrisy and Self-Deception in Hawthorne's Fiction. New York: Cambridge University Press. Hawthorne, N. (1983) Selected Short Stories. Greenwich: Fawcett Publishing.

Kaul, E. (1966). Critical Essays. Englewood Cliffs. New Jersey: Prentice - Hall, Inc.

Kaul, E. (1966). Hawthorne: A collection of Critical Essays. A. N. New Jersey: Prentice- Hall.

Male, R. (1957). Hawthorne's Tragic Vision. New York: w. w. Norton \& Co. Inc.

Mellow, J. R. (1980) Nathaniel Hawthorne in His Times. Boston: Houghton Mifflin Company.

Miller, E. H. (1991). Salem is my Dwelling Place: A Life of Nathaniel Hawthorne. Iowa City: University of Iowa publications.

Newberry, F. (2003). Hawthorne's Gentle Boy, Lost Meditation in Puritan History. Cambridge: Cambridge University Press. 
Page citation: http://www.hawthorneinsalem.org/page/10482/ Accessed on 27 ${ }^{\text {th }}$, May 2012.

Parker, H. (1996). Hawthorne and his Mosses. Herman Melville: A biography, Vol.1 1819-1850. John Hopkins University Press.

Patricia, A. C. (1977). Hawthorne's Functional Settings. A Study of Artistic Method. Amsterdam: Editions Rodopi N.V.

Pearson, N. H. (1999) The Hawthorne Treasury. The Complete Novels and Selected Tales of Nathaniel Hawthorne. New York: The Modem Library.

Pennell, M. (1991). A Nathaniel Hawthorne Encyclopedia. New York: Greenwood Press.

Person S. L. (2007). The Cambridge Introduction to Nathaniel Hawthorne. Cambridge: Cambridge University Press.

Pojman, L. P. (2000). The moral Life: An Introductory Reader in Ethics and Literature. New York: Oxford University Press.

Salinger, S. V. ( 2002). Taverns and Drinking in Early America. Baltimore: Johns Hopkins. UP.

Stewart, R.(1984). Hawthorne's Female Characters. In Nathaniel Hawthorne: A Biography. New Haven: Yale University Press.

Tharpe, J. (1967). Nathaniel Hawthorne: Identity and Knowledge. Carbondale: Southern Illinois University Press. 